\title{
Manipulation and distortion in literal and artistic works under Iranian criminal law: criminological study
}

\begin{abstract}
The crime of manipulating and distorting the literal and artistic works and publishing them, because of literary and artistic property rights which is itself a branch of intellectual property rights, is punishable and has a criminal enforcement guarantee. This crime is a deliberate act with the general malicious aim and is conceivable both in form of act and abandoning the action. Anyone can commit the crime except the creator. The criminal enforcement guarantee of this crime which is the subject of article 19 of the Authors, Compilers and Artists' Rights Protection Law, act 1969, is mentioned in the article of the law which consists of correctional imprisonment from three months to 1-year, and with this penalty, there is the possibility if publishing the contents of the sentence in a newspaper according to the demand of the private plaintiff preventing the publication, distribution and supply of complaints and confiscating them. Compensation also must be paid beside the penalty. In this case, crime pursuit is possible only with the private plaintiff's complaint and the Criminal Court has jurisdiction to find out the crime of changing and distorting literary and artistic works and publishing them; of course, this can be followed in Dispute Settlement Centers.
\end{abstract}

Keywords: literary property rights, author, composer, work, creator
Volume I Issue 4 - 2015

\author{
Mahmoud Malmir,' Ehsan Zarrokh, ${ }^{2}$ Mina \\ Agha Mir Ali Akbar ${ }^{2}$ \\ 'Assistant Professor of Islamic Azad University, Iran \\ ${ }^{2}$ Islamic Azad University, Iran
}

Correspondence: Ehsan Zarrokh, PhD Candidate in Criminal law \& Criminology, Islamic Azad University, Kermanshah branch, Kermanshah, Iran, Tel 989183395983 ,

Email zarrokh2007@yahoo.com

Received: October 24, 2015 | Published: December 3, 2015

\section{Introduction}

In the current era and with developing knowledge and the increase of literary and artistic works, the need of protecting authors', artists', translators', photographers' and others' rights are being felt even more than before. Some laws have been passed in Iran with the aim of protecting the rights such as the law of the marks and patents in 1931 and after that, the first law with the aim of protecting Intellectual Property was passed in 1969 under the title of (Authors, Compilers and Artists' Rights Protection Law). This law supports the punishment of crimes, which are committed about literal, artistic and even cinematic works and besides explaining some concepts, it has also described the punishments and their different aspects. However, these laws have seldom been discussed and identified. So in this article an attempt is made to discuss the crime of changing and distorting literary and artistic works which is the topic of the article 19 and also the punishment related to this crime in order to protect the artistic works. At first, we investigate the concepts needed for identifying some words. Then, we investigate the creator's rights reserved and after that, we are going to identify the elements of this crime and we want to know what type of behavior forms the element of this crime. Finally, we are going to identify the legal cases of changing and distorting literal and artistic works.

\section{General topics}

\section{Concepts}

\section{Intellectual property rights}

Intellectual property is a legal concept based on which the way of protecting and using humans' intellectual works have been determined. On the one hand, Intellectual property protects the creator of the work and on the other hand; it respects the creator's rights. ${ }^{1}$ Also it can be mentioned that (Intellectual Property rights in the broad meaning of the word mean the rights due to creations and intellectual creativity in scientific, industrial, literal and artistic areas). ${ }^{2}$ Intellectual Property Rights has two main branches (Industrial Property and LiteralArtistic Property) which have fundamental differences in nature, rules and topics.

\section{Industrial property}

It contains two types of rights about inventions and innovations, and also distinguishing marks containing marks and Trademarks. ${ }^{3}$ As this subject is off-topic, this amount of explanation suffices.

\section{Literal and artistic property}

Literal and Artistic Property is one of the components of Intellectual Property in which different works of art and literature like book, song, Carol, play, photography and ... And the protections of their creators. ${ }^{4}$ Also Zarkalam ${ }^{4}$ considers Literal and Artistic Property Rights an expression which infers the artist or author's temporary monopoly of financial exploitation compared to his or her work. And in the broad of the word, it contains all known intellectuals and non-intellectual rights for the author of an intellectual work. ${ }^{5}$ (Literal and Artistic Property is the creator's right of the literal, artistic and scientific works and thus

${ }^{1}$ Alasti Sanaz, literary and artistic property, criminal law, first published in Tehran. Mizan Publisher. 2004;13 p.

${ }^{2}$ Mir-Hosseini Seyed Hassan, Introduction to intellectual property rights, second edition, Tehran. Mizan Publisher. 2006;21 p.

${ }^{3}$ Zarkalam Sattar. Literary and artistic property rights, Tehran, Samt publisher. 2008; 4 p.

${ }^{4}$ Alasti Sanaz. Literary and artistic property, criminal law, first published in Tehran, Mizan Publisher. 2004;14 p.

${ }^{5}$ Zarkalam Sattar. Literary and artistic property rights, Tehran, Samt publisher. $2008 ; 8$ p. 
should register by his or her name and it's the creator's copyright to reproduce, deal out, carry out or exploit the work). ${ }^{6}$

\section{Copyright}

It's a set of laws identified by the law from the creator to his or her created ideas and intelligence. These rights contain the exclusive right of exploitation of the creator for a limited time to the profit of the creator and to his or her heirs after the creator's death. ${ }^{7}$ Dr. Mirhosseini's belief (Copyright is a legal term and contains the rights dedicated to the creators of literal and artistic works) ${ }^{8}$ To summarize, it can said that: (the rights because of the Literal-artistic Properties termed author's copyright or authors' copyrights'). ${ }^{9}$ (The creator's right (the author's right) is the legal, lawful and guaranteed right, which serves the purpose of protecting the creator's Rights Reserved and exploiting these rights dedicated to the creator of original and

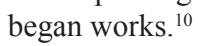

\section{Historical background of the creators' rights in Iran}

No documented information is available about attentions and respect to the creator's rights of artistic and literal works in old Persia until the arrival of Islam and after that until the present-day era. However, respect and dignity the poets, orators and other artists had in kings' courts was unique. Authors and poets also reminisce over each other with respect and when quoting, they mentioned the author's name. In fact, the literary industry of (Assurance) supervises such quotations from other poets and shows the respect to intellectual works of others. ${ }^{11}$ Although the author's right in Europe and the U.S. has a history of two centuries; the first approach to this in Iran must searched for in the articles 245-248 of the eleventh chapter, the conspiracy and fraud topic in business of the criminal law approved in July 1931. These articles assigned compensation for committing crimes such as publishing a compilation without the author's permission, using the author's works in one's work without mentioning the source, selling or bringing others' works to another country and publishing the others' compilations under the name of someone who is not the original author. These articles were translating the articles 425 to 429 of criminal law in France. ${ }^{12}$

After that, in 1955, a plan in nine articles presented to the legislative assembly which forgotten because of some major problems. Also, in 1957, the compilation and translation bill which presented by the government to the senate failed. ${ }^{13}$ Finally in 1967, the Ministry of Culture and Art provided the bill of (protecting the authors and artists) and it approved in Dei 1969. ${ }^{14}$ This law contains 33articles and some of its parts dedicated to penal rules and thus the literal - artistic works supported more by the legislators from then on. In Dei 4th, 1971,

${ }^{6}$ Mir-Hosseini Seyed Hassan. Introduction to intellectual property rights, second edition, Tehran, Mizan Publisher, 2006, p233.

${ }^{7} \mathrm{Ja}$ 'afari Langaroodi, Mohammad Jafar. Property rights, second edition, Tehran, Ganj e Danesh publisher. 1991;164 p.

${ }^{8}$ Mir-Hosseini Seyed Hassan. Introduction to intellectual property rights, second edition, Tehran, Mizan Publisher. 2006;233 p.

${ }^{9}$ Alasti Sanaz. Literary and artistic property, criminal law, first published in Tehran, Mizan Publisher. 2004;14 p.

${ }^{10}$ Ibid. $15 \mathrm{p}$.

${ }^{11}$ Zarkalam, Sattar, literary and artistic property rights. Tehran Samt publisher. 2008; 13 p.

${ }^{12}$ Ayati H. Rights of intellectual creation, printing. Tehran Hoqoqdan Publisher. 1996;47 p.

${ }^{13}$ Ibid. 48 p.

${ }^{14}$ Alasti Sanaz. Literary and artistic property, criminal law, first published in Tehran. Mizan Publisher. 2004;28 p. the executive by-law of the above- mentioned law approved by the jury. The law of translation and duplication of audio books approved in 1973 and the minutes of comprehensive legislation of protecting Literal - Artistic Property currently developed with the help of World Intellectual Property Organization (WIPO) which will send to the authorities for approval in a near future after the final review. ${ }^{15}$

\section{Material right}

The right to exploit only from copying, showing or sharing the product which holds financial interests called material right. Of course, as all the rights are non-material and slight and are perceivable only through human's mind and in other words, the which accrues to the right is material and not the itself dividing the properties to material and non-material is not applicable to the related rights. ${ }^{16}$

\section{Features of material right}

\section{Transferability}

Author's material rights are transferable. According to the article 5 of the Authors, Writers and Artists' Rights Protection Law approved in 1969; the writer can transfer all or part of his or her material rights to another person. This transfer can be free. Also, writer's material rights are transferable through will and heritage. ${ }^{17}$

\section{Being temporary}

(Writer's material rights are provisional. Because of the LiteralArtistic work created for public use and the work which remains will be the intellectual and spiritual property of the society.). ${ }^{18}$ Material right limited to a certain time and about the author's right law of each country, this time varies. It means that after the mentioned time in the law, the product will be part of a social property, and each person can exploit it with considering spiritual rights of the creator. ${ }^{19}$

\section{Spiritual right}

Spiritual rights are legal and non-material advantages and related to the creator of the intellectual work and because of this right; the person will always have certain rights. Spiritual rights have always considered by authors and poets in Old Literature texts. For instance, in his unique work called Shahnameh, ${ }^{20}$ hakim Abolghasem Ferdowsi has repeatedly pointed to exploit a knowledgeable farmer, who had gathered old stories in a collection called (Khodainame) or (Khodainamak) at least four hundred years before Ferdowsi, and thus he has honored his moral right. ${ }^{21}$ (This right is apart from the author's material right and will keep for the creator even after transferring the material right of the work). ${ }^{22}$

\section{Features of spiritual right}

\section{Non-transferability}

${ }^{15}$ Ibid. 29 p.

${ }^{16}$ Ayati H. Rights of intellectual creation, printing, Tehran. Hoqoqdan Publisher. $1996 ; 115$ p.

${ }^{17}$ Mir-Hosseini Seyed Hassan, Introduction to intellectual property rights, second edition, Tehran, Mizan Publisher. 2006;245 p.

${ }^{18}$ Ibid, p146.

${ }^{19}$ Alasti Sanaz. Literary and artistic property, criminal law, first published in Tehran, Mizan Publisher. 2004;18 p.

${ }^{20}$ See: http://en.wikipedia.org/wiki/Shahnameh

${ }^{21}$ Ayati H. Rights of intellectual creation, printing, Tehran. Hoqoqdan Publisher. 1996;134 p.

${ }^{22}$ Mir-Hosseini Seyed Hassan, Introduction to intellectual property rights, second edition, Tehran. Mizan Publisher. 2006;249 p. 
There are disagreements about this feature among some recommends: Katouzian ${ }^{6}$ in his book called (an introduction to the law science) writes about non-transferability of spiritual right as: (we must know that author's right classified into two distinguished rights:

i. The right to publish and exploit the work which has financial and will transferred to the author's heirs beside other properties.

ii. Spiritual right which dedicated to the author and is, in fact, part of his or her personality. ${ }^{23}$

Spiritual right to the work should obeyed by the heirs as it is but the original right did not transfer to them, as the author can manipulate his or her text, give ideas, which contrast with his or her previous beliefs and or destroy them, but the heirs do not have such). Dr. Seyed Hassan Safaii believes in the transferability of the spiritual right by mentioning some reasons and says: Supporting the creator needs that his or her non-material rights applied by the successors after the creator dies. ${ }^{24}$ Finally, it must state the article 4 of the Authors, Writers and Artists' Rights Protection Law has a clear position on the nontransferability of this law and states that: (The creator's spiritual rights not limited to certain time or place and are non-transferable).

\section{Not limited to a certain time and place}

Despite material rights, spiritual rights not limited to special time or period and are under the name of the creator even after his or her death and pass of time do not decrease its credit. ${ }^{25}$ And it not limited to a place and the work must support in any country. ${ }^{26}$

\section{Respect right of the work}

One of the several of spiritual right is the respect right to the work and contains two of positive and negative. The first is the creator only has the right to change his or her work, add to its content, delete or move some parts and even offer ideas against his or her past notions. ${ }^{27}$ The negative of the respect right guarantees to prevent others from changing or distorting through the creator and defending the whole parts of the work. The legislator has predicted some punishments for the violators so the creator can have the necessary defense tools against any violation and offence ${ }^{28}$ which we will talk about later. The article 19 of the Authors, Writers and Artists' Rights Protection law states: (Any change or violation in the works protected by this law and their publication without permission forbidden). In the bill minute of the literal and artistic rights, there are thorough rules about the spiritual rights of the author. According to this bill, the creator will have the following rights as well as his or her material rights even after the person is not the owner of the work any longer:

i. (Subparagraph (A), section 1, article 7 of the mentioned bill minute: Writing in the creator's name clearly on previous versions of the work and about any use by the public in a way that it is practical.)

ii. (Subparagraph (C), section 1, article 57 of the literal and

${ }^{23}$ Katouzia, Nasser. introduction to the study of jurisprudence and legal system of Iran, published thirty-third, Tehran. Sahami Enteshar Publisher. 2003;299 p.

${ }^{24}$ Ayati H. Rights of intellectual creation, printing, Tehran, Hoqoqdan Publisher. 1996; $134 \mathrm{p}$.

${ }^{25}$ Ibid, p 137.

${ }^{26}$ Alasti Sanaz. Literary and artistic property, criminal law, first published in Tehran, Mizan Publisher. 2004;19 p.

${ }^{27}$ Ayati H. rights of intellectual creation, printing, Tehran, Hoqoqdan Publisher. 1996;140 p.

${ }^{28}$ Ibid, p 141. artistic rights protection bill minute states: Objection to any manipulation, distortion or changing the work or other assaulting acts to the work may damage his or her reputation. ${ }^{29}$

\section{Ingredients of manipulation or distortion of literal and artistic works crime \\ Legal}

i. Article 19 of the Authors, Writers and Artists' Rights Protection Law: (Any manipulation or distortion in the works protected by this law and their publication without the creator's permission forbidden).

ii. And article 25 of the same law states: (Violators of the articles $17,18,19$ and 20 of this law will sentenced to correctional imprisonment from three months to one year.)

\section{Material}

The material of this crime is (manipulation or distortion of the works protected by the Authors, Writers and Artists' Rights Protection Law) and their publication without the creator's permission. Therefore, it is first necessary to find out the criminal behaviour of this crime and then mention the subject of this crime which is the works protected by this law.

\section{Criminal behaviour}

\section{Manipulation}

In Moein's Persian Dictionary ${ }^{30}$ it means turning and transforming and (manipulation) means to turn one into another form. ${ }^{31}$

\section{Distortion}

Conceptually, it means changing and converting the speech from the original position and even changing some letters of a word..$^{32}$ And in amid's dictionary ${ }^{33}$ as well as these, it also means changing the word's meaning; and in another place it means changing the speech and something from its current position. ${ }^{34}$

\section{But in legal, distortion}

Any change or change-over in the text, content or form of the work and it means the change of Scientific-Literal creator's ideological identity and personality and such distortion and change-over are subreption $^{35}$ and subreption is taboo in Islam as the censorship of the work is hiding the knowledge and is taboo. ${ }^{36}$

${ }^{29}$ Mir-Hosseini Seyed Hassan. Introduction to intellectual property rights, second edition, Tehran, Mizan Publisher. 2006;251 p.

${ }^{30}$ Moin Mohammad. Certain Persian Culture, Volume I, Eleventh Edition, Tehran, Sepehr Publisher. 1997;1107 p.

${ }^{31}$ Amid Hassan. Amid the Persian culture, Twentieth Edition, Tehran. Sepehr Publisher. 2001;406 p.

${ }^{32}$ Moin Mohammad. Certain Persian Culture, Volume I, Eleventh Edition, Tehran. Sepehr Publisher. 1997;1037 p.

${ }^{33}$ Amid Hassan. Amid the Persian culture, Twentieth Edition, Tehran, Sepehr Publisher. 2001;1999 p.

${ }^{34}$ Soufi M. A teacher of Persian culture, Printing, Tehran. Farayen Publisher. 2001;282 p.

${ }^{35}$ See: http://en.wikipedia.org/wiki/Subreption

${ }^{36}$ Alasti Sanaz, literary and artistic property, criminal law, first published in Tehran. Mizan Publisher. 2004;77 p. 


\section{Publication}

In another part of the article, also change and distortion of the protected works, there is a section of publishing this change and distortion. In fact (distorting a work has a condition and it is its reveal. As the word (publication) used in the article, the criminal must publish the work after distorting it and make it available to the public but if the criminal does not do it and keep it with him or her and do not declare it, it is out of the article inclusion. ${ }^{37}$ It can imply from the article that (This crime is true with both acting and leaving the act. About the criminal behaviour in the form of action about the clearness of the article, any manipulation or distortion of the work before its publication will be subject to this article. About leaving the act, it can state that: (for instance, a projectionist, who does not show a scene of a movie, has committed distortion by his act. ${ }^{38}$

i. What conditions must be the criminal of the article 19 of the Authors, Writers and Artists' Rights Protection Law has? The criminal can be anyone except the creator of the work because he or she has the right to change the work as the time passes and add to the content or remove some parts because the spiritual rights of the work belong to him or her, and another person can change the work with the creator's permission only. ${ }^{39}$

ii. Is the crime of manipulation, distortion and publication a crime or a conditional one? We know the conditional or material crime is the one which has the result wanted by the criminal and the crime is the one which is not dependant on the got result. ${ }^{40}$ About the crime of the article 19 of the mentioned law, distorting and manipulating another person's work and publishing it is a crime and does not the result and is a crime. ${ }^{41}$

iii. Is the crime of the article 19 of the Authors, Writers and Artists' Rights Protection Law a sudden crime or a continual one?

Sudden crimes are those which have a material and committed in a short time. ${ }^{42}$ With this definition, it clarified the crime of literal works distortion and manipulation is a sudden crime and is different from continual crimes whose commitment and realization time takes time.

The crime topic: protected works by the authors, writers and artists' rights protection law approved in 1969

First, it is necessary to explore the work and creator. Then the conditions of protecting the work and finally, the works protected by this law will mention.

\section{Literal and artistic work}

Iranian legislator states in the article 1 of the Authors, Writers and Artists' Rights Protection Law in defining the work: (... To what which gained through knowledge, art or creativity, without considering the style or method used in mentioning or creating it, called (the work)).

\footnotetext{
${ }^{37}$ Ibid.

${ }^{38}$ Ibid, p 78.

${ }^{39} \mathrm{Ibid}$.

${ }^{40}$ Goldouzian I. The requisite general criminal justice, 12th ed, Tehran, Mizan Publisher. 2005;187 p.

${ }^{41}$ Alasti Sanaz. Literary and artistic property, criminal law. First published in Tehran, Mizan Publisher. 2004;78 p.

${ }^{42}$ Goldouzian I. The requisite general criminal justice, 12 th ed, Tehran, Mizan Publisher. 2005;187 p.
}

Dr. Emami talks about creating the work or intellectual creation as: (the work is the original product resulted from the free mental effort of a person which expressed in a special shape and form) ${ }^{43}$ Also, in law expression and for the literal meaning of the literal work, it can state that: (Literal creation is any clear and harmonic text, which is effective in developing a person's feeling and devising the intellectual changes).$^{44}$ In the law of Iran and in the law of the authors, writers and artists' rights protection, artistic works mentioned spasmodically and in various sections of the article 2. Distinguishing literal works from artistic and technical works may not be a sharp distinguish; as it looks as if an art can found in all the created works and it can felt; although artistic works like music, painting and decorative works address the soul and feeling of the people more and have a key role in satisfying people's mind and internal emotions and scientific and literal works are more applicable in mind development and improvement, but literal work will result in caressing the soul and stylizing the emotions in the form of poem and rhythmic words or prose and beautiful words. Therefore, distinguishing literal works from artistic works does not seem that logical. ${ }^{45}$

\section{Creator}

Article 1 of the Authors, Writers and Artists' Rights Protection Law approved in 1969, considers authors, writers and artists the creators. In fact, the legislator of Iran combines the creator with originality and in fact, considers the creator someone who has created the literal and artistic work because his or her initiative and innovation. ${ }^{46}$ But the mentioned law does not define writer, author and artist, so we will look into them later in this article.

\section{i. Compiler}

It means writer and the person who has gathered the content of a book. ${ }^{47}$ In legal terms; Compiler is someone who overcomes the inventions and scientific works of others in making a new work, thoughts and notions of others. ${ }^{48}$

\section{ii. Author}

In Amid Dictionary, ${ }^{49}$ it means a person who writes a book. Author means collector and writer of a book or article and in the law of compiler's rights protection of Iran; the creator of an intellectual work called the author. Some recommends have distinguished between compiler and author and believe that in writing, the prestige and the creative of the writer domineer but in compiling, thoughts and texts from others mostly used. However, according to the article 1 of the authors, compilers and artists' rights protection law, there is no difference between a compiler and an author. ${ }^{50}$

${ }^{43}$ Emami Asadullah. Intellectual property rights, first Edition, Tehran, Mizan Publisher. 2007;93 p.

${ }^{44}$ Ibis, p 100

${ }^{45}$ Ibis, $\mathrm{p} 117$

${ }^{46}$ Zarkalam Sattar. Literary and artistic property rights, Tehran, Samt publisher. $2008 ; 84 \mathrm{p}$

${ }^{47}$ Amid Hassan. Amid the Persian culture, 12th ed, Tehran. Sepehr Publisher. 2001;1044 p.

${ }^{48}$ Emami Asadullah, intellectual property rights, 1st ed, Tehran, Mizan Publisher, 2007;126 p.

${ }^{49}$ Amid, Hassan, Amid the Persian culture, 12th ed, Tehran, Sepehr Publisher. 2001;1109 p.

${ }^{50}$ Emami Asadullah, intellectual property rights, 1st ed, Tehran, Mizan Publisher. 2007;127 p. 


\section{iii. Artist}

As it mentioned above, in the Authors, Writers and Artists' Rights Protection Law, there is no definition for this word. Dr. Emami believes that: from what the legislator states, it can end that an artist is different from an author or compiler. And considering an artist with the same rank as a compiler or an author is not exact and principled. ${ }^{51}$ (In Persian diction and grammar, the word (artist) is a subjective adjective and refers to a person who has personal in Fine Arts or creates artistic works). ${ }^{52}$ And finally, Dr. Emami defines an artist in a certain meaning as: (An artist is someone who penetrates the souls of the audience by creating an intellectual and artistic work or by performing an artistic work and makes a worthy spiritual revolution in others by transferring his or her emotions). ${ }^{53}$

\section{The conditions of the work needed for protected by law}

The sensibility of the work form: (Thoughts and notions are not protectable until they are more than a mental imagination and embodied as an object and, protecting a notion which does not exist in the outer world is meaningless). ${ }^{54}$ (Music that recorded, a story, which written and a photo which taken and saved in a camera are all types of works that have tangible forms). ${ }^{55}$ Originality of the work: (a work is protectable that is creative and original which means that it is a symbol of the creator's personality and statements and a reflection of his ideas, but the novelty of the work is not the condition). ${ }^{56}$ In contrast, Ayati believes that: Although there are obviously differences between the (originality of the work) which means the result of the creator's thoughts alone and the (creativity of the work) which mean novelty of the work and not being a repetition, some law professors use them interchangeably. ${ }^{57}$ Prof. Seyed Hossein Safaii states that: a work is protectable, which is original and in other words, is creative. ${ }^{58}$ The legislator has used the words (creativity) and (innovation) in the articles 1 and 2 of the authors, compilers and artists' rights protection law and has paid attention to this matter. Dr. Zarkalam states that: Although literal and artistic works are often fresh, being fresh is not a necessary condition for protecting these works. The main in protecting artistic and literal works is the role of the creator's personality reveals in the work under discussion. ${ }^{59} \mathrm{~A}$ work which created by taking images from a tableau or an adoption from a statue will protected by the law as much as the creators of the early works are. In fact, the originality of a work evaluated according to the subjective, so there is hardly ever doubt about it and in other words, what considered the condition of protections is the work must be the symbol of the creator's personality. ${ }^{60}$

Originality can be of two types:

i. Originality in content: it means the creator must be the first

${ }^{51}$ Ibid. $129 \mathrm{p}$.

${ }^{52}$ Ibid. $130 \mathrm{p}$.

${ }^{53}$ Ibid. $131 \mathrm{p}$.

${ }^{54}$ Alasti Sanaz, literary and artistic property, criminal law. Mizan Publisher. 2004;39 p.

${ }^{55}$ Ibid.

${ }^{56}$ Ibid.

${ }^{57}$ Ayati H., rights of intellectual creation, printing, Tehran. Hoqoqdan Publisher. 1996;77 p.

${ }^{58}$ Ibid.

${ }^{59}$ Zarkalam, Sattar, literary and artistic property rights, Tehran. Samt publisher. 2008;46 p.

${ }^{60}$ Ibid. 47 p. person to create it like an author who writes the events of a story for the first time.

ii. Originality in interpretation: the work creator uses the content which has been in existence from the past times and creates another work, which has creativity like translated texts, a poem written for a proverb, adapted films and ... and all of them have the feature of originality). ${ }^{61}$

The result is the two of (Novelty) and (Originality) must not considered the same and the creator of a literal and artistic work must not deprived of legal protection because his or her work is not novel; in other words, the work must protected just if it is attributable to the creator and results from his or her intellectual flows regardless of it is novel or not. ${ }^{62}$

\section{Publication, distribution or performance for the first time in Iran}

The article 22 of the authors, compilers and artists' rights protection law: (Creator's material rights will be protectable when the work published, shared or performed for the first time in Iran and not in any other countries). (According to this law, the material right of a Persian work which published, dealt out or performed in another county other than Iran will not protected by this law). ${ }^{63}$ The law minute of the literal and artistic ownership has considered the of being an Iranian citizen or living in Iran as well as first publishing the work in Iran or publishing it within 30 days from first publishing the work in Iran. ${ }^{64}$

\section{Profitability of the work}

(Legally, the profitability of a work not limited to its being exchangeable or financial value but the role of custom, social order and morality must consider as well. Especially in the legal system of our country which based on judicial rules, there are some works which are exchangeable but not considered valuable legally and not protected; for instance, according to judicial laws, a pornographic movie, an insulting poem or a naked statue and alike are not protectable works). ${ }^{65}$

\section{Feature's declaration}

Having characteristics or special marks on the works is not a condition of protection in Iran and it is not necessary to write them in on the products but there are exceptions about music or audio CDs or cassettes. ${ }^{66}$ The article 4 of the Books, Journals and Audio Products Translation and Publication Law approved in 1973 explains as follows:

i. (Audio and music CDs and cassettes protected if on each cover or copy, there is the international mark $(\mathrm{P})$ inside a circle and the publication date, the address of the producer, the exclusive agency and the trade mark mentioned.

\footnotetext{
${ }^{61}$ Alasti Sanaz, literary and artistic property, criminal law. Mizan Publisher. 2004;40 p.

${ }^{62}$ Zarkalam, Sattar. Literary and artistic property rights, Tehran. Samt publisher. 2008; 47 p.

${ }^{63}$ Ayati H. Rights of intellectual creation, printing, Tehran. Hoqoqdan Publisher. $1996 ; 80 \mathrm{p}$.

${ }^{64}$ Alasti Sanaz. Literary and artistic property, criminal law. Mizan Publisher. 2004;45 p.

${ }^{65}$ Ayati H. Rights of intellectual creation, printing, Tehran. Hoqoqdan Publisher. $1996 ; 82$ p.

${ }^{66}$ Alasti Sanaz. Literary and artistic property, criminal law. Mizan Publisher. $2004 ; 4$ p.
} 
ii. Work registration: Registering the work in Iran is not a condition of the work identification and its legal protection and the right owner not considered the compiler. Registering the work is necessary in some countries but optional in others, ${ }^{67}$ and according to the article 21 of the authors, compilers and artists' rights protection law, the work (can) shows that registering the literal and artistic work is optional in Iran.

iii. Article 21 of the mentioned law states that: (The creators can register the work, title and the special mark of their work in the centers advertised by the Ministry of Culture and Art. To regulate how to and the order of registration and the authority for accepting registration questions will approved by the Board of Ministers).

However, registering the work is essential because of which are useful to the creator. For instance, registration is part of the statistics for to identify the work owner and when his or her material or spiritual rights violated, it will be useful to prove his or her claim in the court and has the so-called formation affect. ${ }^{68}$ The administrative rule of the authors, compilers and artists' rights protection law approved in 1971 notes the formalities of work registration.

\section{Works protected by of the authors, compilers and artists' rights protection law}

The article 2 of the mentioned law (approved in 1969) mentions the works protected by this law: Books, pamphlets, booklets, scripts and other scientific, technical, literal and artistic writings: the work (other writings) shows these instances are figurative. Any work which proves the personality of its creator will protected by the law such as the articles published in the press, movie scripts and... All the mentioned works are the same in written and are the original text or a converted one like translations, adaptations or summarizations of other works. ${ }^{69}$ Poems, songs, carols and ballads, which written, recorded or published in anyway: From the way the section 1 of the article 2 written, it can understood the protected works not limited to what predicted in sections 1 and 2 of the article 2 and it can include any text.

Therefore, catalogues, forms, calendars, manuals, dictionaries, articles published in the newspapers and interviews and alike can consider text if they are creative and original. ${ }^{70}$ Audio-visual products which written, recorded or published in any way with the purpose of performed on the stages, in the cinema or broadcast from the radio:

Radio work: (By radio work, a work meant that created or adapted to broadcast from the radio. Often, before a work broadcast from the radio, its performance or show must record so it can broadcast from the radio again and again in the future). ${ }^{71}$

TV work: A work which adapted or created to broadcast from the television. ${ }^{72}$

Cinema work: it is a collaborative work because it is the result of the group collaboration. In Iran, it is usual the creators of a movie such as the director assign their financial rights to the producer constantly

${ }^{67}$ Ayati H. Rights of intellectual creation, printing, Tehran. Hoqoqdan Publisher. $1996 ; 88 \mathrm{p}$.

${ }^{68} \mathrm{Ibid} .83 \mathrm{p}$

${ }^{69}$ Alasti Sanaz. Literary and artistic property, criminal law. Mizan Publisher. 2004;51 p.

${ }^{70}$ Zarkalam, Sattar. Literary and artistic property rights, Tehran. Samt publisher. 2008;59 p.

${ }^{71}$ Ayati H. Rights of intellectual creation, printing, Tehran. Hoqoqdan Publisher. 1996;91 p.

${ }^{72}$ Ibid. $97 \mathrm{p}$. which is not compatible to justice. ${ }^{73}$

i. Music work which written, recorded or published in any way. In music works four supported: the melody or the main part of the music, rhythm, harmony and instrumentation. ${ }^{74}$

ii. Painting, picture, creative geographical plan, texts, decorative handwritings and any decorative work, which created in any way in the form of shadow or combinational.

\section{iii. Any statues}

iv. Architectural work such as a building plan

v. Photography work which created in a creative and new way.

vi. Creative work related to handicrafts or industrial arts and rug and carpet plans

vii. Creative work which based on folk-lore or cultural heritage and national art

\section{viii. Technical work which has creativity and imitativeness}

ix. Any other creative work which made up of a combination of several mentioned works.

It seems that for the way the 12 sections of the article 2 written, where the target is the civil protection of the creator's material and spiritual law, we must pay attention to explaining the mentioned work types in article 2 and as the penal support of the works posed, on the fact of crime and legal punishment, just the mentioned works in law must considered by judges and courts. ${ }^{75}$

\section{Spiritual}

The crime of manipulating and distorting literal and artistic works and publishing them for defining intentional crimes classified in this group. (Intentional crimes are those in which the criminal commits it with the purpose of committing the crime which means that by wishing and wanting an action that banned by the law or leaving an action which banned by the law. In other words, the psychological of the crime is the criminal purpose in these types of crime). ${ }^{76}$ Dr. Saneii defines malice or criminal purpose as wishing and wanting to commit a criminal act and wanting its result. ${ }^{77}$ Public malice means the person's conscious will in committing a criminal act. The existence of this malice for realizing the intentional crime is always necessary but inadequate. In some types of crime, as well as public malice, another special malice is necessary, which considered essential by the law. ${ }^{78}$ Not being familiar with the law does not make people free of responsibility and the committee will punished even if he or she does not know that distorting others' work is a crime and the committee must be familiar with the topic and know that a literal or artistic work which belongs to another person protected by the law. Public malice means the person intends to distort and manipulate, which means the person knows the work belongs to another person but still wants to distort it, but this crime is not special malice. ${ }^{79}$

\section{${ }^{73}$ Ibid. 99 p.}

${ }^{74}$ Alasti Sanaz. Literary and artistic property, criminal law, first published in Tehran. Mizan Publisher. 2004;52 p.

${ }^{75}$ Zarkalam Sattar. Literary and artistic property rights, Tehran. Samt publisher. 2008;56 p.

${ }^{76}$ Nourbaha R The field of criminal justice, Eleventh Edition, Tehran. Dadafarin Publisher, 2004;198 p.

${ }^{77}$ Saneii P. Criminal justice, the first volume, Tehran. Ganj e Danesh Publisher. 1997;311 p.

${ }^{78}$ Shambiati Hooshang. Criminal justice, the first volume, 11th ed, Tehran. Majd Publisher. 2003;411 p.

${ }^{79}$ Alasti Sanaz. Literary and artistic property, criminal law, first published in 


\section{Legal cases of manipulation and distortion in literal and artistic works}

About committing crimes related to the creators' rights in Iran, there are cases in which using the work without the creator's permission is legal and if a person commits it, he or she will be free from punishment according to the law and his or her act considered legal (Alasti: 2004, 121). ${ }^{80}$

i. For scientific, literal, technical and educational purposes in the forms of criticism or appreciation (by mentioning the reference) which mentioned in the authors, compilers and artists' rights protection law.

ii. For teaching in institutions without mentioning the reference: The note 7 of the mentioned law. (Mentioning the reference about the booklets which prepared and copied to teach in the educational institutions by the teachers is not necessary if there is no commercial.

iii. According to the article 8 of the authors, compilers and artists' rights protection law, the use in the libraries and institutions which gather journals and educational academic institutions that have a non-government system (for copying the work) (Alasti: $2004,122){ }^{81}$

iv. For personal and private use: the article 11 of the mentioned law accepts this if it does not have a commercial.

\section{Conclusion}

For the limited support of the authors, compilers and artists' rights protection law of the artistic and literal works approved in 1969 and after 40 years passed since, also by the daily improvement of communication and to expand media and the existences of the Internet in the current era, it seems the guarantee for enforcing the law is not currently thorough, plenty and protective and the ways for criminals to escape these rules are easily imaginable. Manipulation and distortion in a work can result in irrecoverable material and especially spiritual harms to the creators and this matter confirms the reconsideration in these rules more than before. By protecting the literal and artistic works more and more accurately, also by lawfully using the works properly, take on and hope in authors, poets, artists and other creators of unique and valuable works has increased and as a result; it's scientific, cultural, social and its financial effects will revealed in the society. Manipulation and distortion in these works and using them might be just moving a few words or sentences in some people's opinion but for the creators, this means destroying the body of their works.

Therefore, by identifying this crime and making the users of these works familiar with the mentioned punishments for protecting the creators' rights, a serious step will taken for protecting the openminded and hard-working class in the science, literature and art. Therefore, for the mentioned topics and the given result, the following subjects recommended:

i. For preventing creators' rights violation, the knowledge of the creators to the guarantees and the literal and artistic ownership

Tehran. Mizan Publisher. 2004;78 p.

${ }^{80}$ Ibid. $121 \mathrm{p}$.

${ }^{81}$ Ibid. 122 p. rules must increased and suitable punishment guarantees about these crimes and under current improvements must sought on so eventually, the definite support of literal and artistic works realized.

ii. It is better to oblige the work registration to protect the literal and artistic works: because according to the article 21 of the authors, compilers and artists' rights protection law, the word (can) shows that registering the work is optional and this mater makes identifying the owner of the work difficult in the lawsuit.

iii. Also, according to the article 31 of the mentioned law, prosecuting the mentioned crimes in this law begins with the complaint from the plaintiff and stops with his or her forgiveness, and this matter does not seem suitable for the importance of the crimes mentioned in this law, especially the crime of distortion and manipulation in the literal and artistic works as the creator might not told about the change or distortion and in this case, there is no chance for investigation and chasing the criminal who is a real abuse to the creator.

\section{Acknowledgments}

None.

\section{Conflicts of interest}

The author declares that there are no conflicts of interest.

\section{References}

1. Alasti Sanaz. Literary and artistic property, criminal law. Mizan Publisher. 2004;13 p.

2. Mir-Hosseini Seyed Hassan. Introduction to intellectual property rights, 2nd ed. Mizan Publisher. 2006.

3. Zarkalam Sattar. Literary and artistic property rights. Samt publisher. 2008;4.

4. Ja'afari Langaroodi, Mohammad Jafar. Property rights, second edition. Ganj e Danesh publisher. 1991.

5. Ayati H. Rights of intellectual creation. Hoqoqdan Publisher. 1996;47.

6. Katouzian Nasser. Introduction to the study of jurisprudence and legal system of Iran. Sahami Enteshar Publisher.

7. Moin Mohammad. Certain Persian Culture. 11th ed. Sepehr Publisher. 1997;1107 p.

8. Amid Hassan. Amid the Persian culture, 12th ed. Sepehr Publisher. 2001;406 p.

9. Soufi M. A teacher of Persian culture. Farayen Publisher. 2001;282 p.

10. Goldouzian I. The requisite general criminal justice, 12 th edn. Mizan Publisher. 2005;187.

11. Emami Asadullah. Intellectual property rights, 1st ed. Mizan Publisher. 2007;93 p.

12. Nourbaha R. The field of criminal justice, 7 th ed. Dadafarin Publisher. 2004;198 p.

13. Saneii P. Criminal justice. Ganj e Danesh Publisher. 1997;311 p.

14. Shambiati Hooshang. Criminal justice, 12th ed. Majd Publisher. 2003;411 p. 